\title{
Surgical second-look in epithelial ovarian cancer: high recurrence rate after negative results and lack of survival benefit limits its role in standard management
}

\author{
Epitelyal over kanserlerinde ikinci-bakı operasyonu: Negatif sonuçlardan sonra \\ yüksek nüks oranı ve sağkalıma katkısının olmaması prosedürün standart \\ yaklaşımdaki yararını sınırlamaktadır
}

\author{
Salih Taşkın, Mete Güngör, Elif Aylin Taşkın, Fırat Ortaç \\ Department of Obstetrics and Gynecology, Medical School, Ankara University, Ankara, Turkey
}

\section{Abstract}

Objective: To evaluate the role of surgical second look (SSL) in epithelial ovarian cancer.

Material and Methods: One hundred and seventy-one patients clinically free of disease were assessed retrospectively. Ninety-eight (57.3\%) patients underwent SSL and $73(42.7 \%)$ were observed. Fifty-one (52.0\%) of the SSL operations were negative, 31 (31.6\%) microscopically positive, and $16(16.3 \%)$ macroscopically positive. Cytoreduction andor chemotherapy were administered after positive SSL. Negative SSL and observation group patients were observed without treatment until recurrence was detected. Disease free survival (DFS), overall survival (OS) and clinical characteristics of groups were compared.

Results: While DFS and OS of negative SSL group were better than the observation, microscopic and macroscopic positive SSL groups $(\mathrm{p}<.01)$, no significant difference was found between positive SSL and observation groups ( $p>.05)$. However, DFS and OS of the microscopic positive SSL group were significantly longer than the macroscopic positive SSL group $(\mathrm{p}<.01)$. Thirty-two patients have had recurrences (62.8\%) after negative SSL. Only the use of paclitaxel as first-line chemotherapy was seen to prevent recurrence after negative SSL $(p<.05)$. Recurrence after negative SSL was not affected by stage, grade, age, CA-125 level, ascites volume, histologic type or optimal cytoreduction.

Conclusion: Rate of recurrence after negative SSL remains high, and secondary efforts following positive SSL could not lead to an obvious survival benefit. Therefore, routine use of SSL seems ineffective and unnecessary. (J Turkish-German Gynecol Assoc 2011; 12: 21-5)

Key words: Surgical second-look, ovarian cancer, recurrence, survival

Received: 4 November, 2010

Accepted: 17 November, 2010

\section{Introduction}

Surgical second-look (SSL) was introduced to evaluate response of an ovarian malignancy to primary surgery and chemotherapy four decades ago. However, its incorporation to standard management of epithelial ovarian cancers is still controversial. SSL is offered to patients clinically free of disease, based on physical examination, CA-125 and imaging

\section{Özet}

Amaç: Cerrahi ikinci-bakı'nın (CiB) epitelyal over kanserindeki rolü araştırılmıştır.

Gereç ve Yöntemler: Klinik olarak hastalıksız olan 171 hasta retrospektif olarak değerlendirilmiştir. 98 (\%57.3) hastaya CiB uygulanmış ve $78(\% 42.7)$ hasta takip edilmiştir. CiB yapılanların 51 (\%52.0)'inde hastalık saptanmazken, 31 (\%31.6) mikroskopik pozitif ve 16 (\%16.3) makroskopik pozitifti. Pozitif CiB sonucu olanlara sitoredüksiyon ve/veya kemoterapi uygulanmıştır. Negatif $\mathrm{CIB}$ ve gözlenen grup ise nüks saptanana kadar tedavisiz takip edilmiştir. Gruplar hastalıksız sağkalım, toplam sağkalım ve klinik karakteristikler açısından karşılaştırılmıştır.

Bulgular: Hastalıksız sağkalım ve toplam sağkalım negatif CiB grubunda gözlem grubuna, mikroskopik ve makroskopik gruplara göre daha iyi olsa da $(\mathrm{p}<.01)$, pozitif Cỉ grubu ile gözlem grubu arasında fark yoktu ( $p>.05)$. Ancak hastalıksız sağkalım ve toplam sağkalım oranları mikroskopik CiB grubunda makroskopik pozitif CiB grubuna göre anlamlı düzeyde uzundu $(\mathrm{p}<.01) .32$ hasta $(\% 62.8)$ negatif CiB sonucundan sonra nüksetmiştir. Sadece ilk kemoterapide paklitaksel kullanımı negatif CiB sonucundan sonra daha az nüks oranıyla ilişkilidir $(\mathrm{p}<.05)$. Negatif CỉB sonrası nüks ile evre, grade, yaş, CA-125 düzeyi, asit hacmi, histolojik tip ve optimal sitoredüksiyondan etkilenmemektedir.

Sonuç: Negatif CiB sonrası nüks oranı halen yüksek olup, pozitif CiB sonrası ikincil çabalar sağkalım için net bir yarar sağlamamaktadır. Bu nedenle rutin CiB uygulaması etkin ve gerekli değildir.

(J Turkish-German Gynecol Assoc 2011; 12: 21-5)

Anahtar kelimeler: Cerrahi ikinci-bakı, over kanseri, nüks, sağkalım

Geliş Tarihi: 04 Kasım 2010

Kabul Tarihi: 17 Kasım 2010

studies, in order to define actual disease status, obtain prognostic information, identify the patients who might benefit from additional therapy such as chemotherapy or secondary cytoreduction finally resulting in improvement in survival. Noninvasive techniques remain unreliable to determine "complete response", so that nearly half of these patients turn out to be "positive" either macro- or microscopically after SSL, which is the gold standard for identifying residual disease (1). 
On the other hand, recurrence rate approximates 50\% after a negative SSL (2). Furthermore, a salvage chemotherapy proven to be effective is unfortunately absent for the cases shown to have persistent or progressive disease in SSL. Therefore, whether SSL provides either reliable prognostic information or survival benefit is questionable. In this study, we evaluated our experience with SSL in order to assess survival benefits of SSL and recurrence risk after negative SSL.

\section{Patients and Methods}

A total of 171 patients with epithelial ovarian cancer who underwent comprehensive staging surgery and treatment with platinum-based chemotherapy between January 1991 and December 2004 at Ankara University Faculty of Medicine, Department of Obstetrics and Gynecology, Gynecologic Oncology clinic were enrolled to this study and grouped into observation $(n=73)$ and SSL $(n=98)$ arms after their informed consents were obtained. According to the classification of the International Federation of Gynecological and Obstetrics (FIGO), 15 cases were classified as stage I, 11 as stage II, 142 as stage III and 3 as stage IV. Using World Health Organization criteria, 22 of the carcinomas were grade 1, 51 were grade 2, and 98 were grade 3 . All patients were clinically disease-free based on physical examination, imaging studies and CA-125 levels at the time of enrollment. Optimal and suboptimal primary cytoreductions were defined as residual disease $\leq 1 \mathrm{~cm}$ and $>1 \mathrm{~cm}$, respectively. Second-look surgery was performed by a gynecologic oncologist, 4 to 6 weeks after completion of primary chemotherapy. The second-look operations were standard secondlook laparotomy or laparoscopy. SSL was performed according to previously defined standards (1). Secondary cytoreductions were performed in cases where tumor removal seemed technically possible.

Three pathologic response categories were defined based on SSL findings and pathologic examination (1). Negative SSL: no evidence of gross disease and negative pathology specimens and peritoneal washing (2). Macroscopic positive SSL: grossly visualized disease confirmed by pathologic examination and (3) Microscopic positive SSL: no macroscopic disease but positive biopsies or positive peritoneal washing.

Patients in the observation arm were treated if disease recurred during follow-up. Patients with negative SSL received no further therapy unless they subsequently relapsed. Microscopic or macroscopic positive SSL cases received salvage chemotherapy, which were individualized on the basis of prior treatment and surgical findings.

Overall survival (OS) and disease free survival (DFS) were defined as the time from the date of primary surgery to either death or recurrence, respectively, or date of last contact. Additionally, patients who died without clinical recurrence were censored.

\section{Statically analyses}

The Kaplan-Meier method was used to estimate the OS and DFS curves. The difference in curves was determined by the log rank method. All indicated P-values are based on two sided significance tests. $\mathrm{P}$ values smaller than 0.05 were reported as statically significant.

\section{Results}

Clinical characteristics of patients were summarized in Table 1. Out of 171 patients, 98 (57.3\%) underwent second-look surgery by laparotomy or laparoscopy (SSL group) and 73 (42.7\%) were observed (observation group). Mean age, histologic type and grade, ascites, optimal cytoreduction rate in primary surgery, and CA125 level at diagnosis were similar in two groups. Advanced stage disease and the use of paclitaxel in first-line chemotherapy were more common in the SSL group than the observation group $(p<.01)$. The majority of SSL were performed by laparotomy (81 cases) and 17 cases by laparoscopy. Fifty-one (52.0\%) of the SSL operations had negative results, 31 (31.6\%) microscopically positive, and 16 (16.3\%) macroscopically positive. The mean followup intervals of the SSL and observation groups were 42.28 and 25.61 months, respectively. Currently, 78 (45.6\%) of all patients have died, while 93 (54.4\%) are alive. In the negative SSL group,

Table 1. Patient characteristics

\begin{tabular}{|c|c|c|c|}
\hline & $\begin{array}{c}\text { SSL } \\
(n=98)\end{array}$ & $\begin{array}{l}\text { Observation } \\
\quad(n=73)\end{array}$ & $\mathbf{p}$ \\
\hline Age, mean (years) & 53.2 & 54.5 & NS \\
\hline \multicolumn{3}{|l|}{ Stage (n, \%) } & \multirow[t]{5}{*}{0.001} \\
\hline I & $3(3.1)$ & $12(16.4)$ & \\
\hline II & $3(3.1)$ & $8(11.0)$ & \\
\hline III & $90(91.8)$ & $52(71.2)$ & \\
\hline IV & $2(2.0)$ & $1(1.4)$ & \\
\hline \multicolumn{3}{|l|}{ Grade (n, \%) } & \multirow[t]{4}{*}{ NS } \\
\hline 1 & $10(10.2)$ & $12(16.4)$ & \\
\hline 2 & $34(34.7)$ & $17(23.3)$ & \\
\hline 3 & $54(55.1)$ & $44(60.3)$ & \\
\hline \multicolumn{3}{|l|}{ Histologic type (n, \%) } & \multirow[t]{7}{*}{ NS } \\
\hline Serous & $83(84.7)$ & $55(75.3)$ & \\
\hline Mucinous & $4(4.1)$ & $9(12.3)$ & \\
\hline Endometrioid & $6(6.1)$ & $6(6.1)$ & \\
\hline Clear cell & $2(2.0)$ & $3(4.1)$ & \\
\hline Mixed & $1(1.0)$ & $2(2.7)$ & \\
\hline Undifferentiated & $2(2.0)$ & $2(2.7)$ & \\
\hline CA-125 (IU/ml) & 496 & 707 & NS \\
\hline Ascites (ml) & 1713 & 1432 & NS \\
\hline Paclitaxel use (n, \%) & $67(68.4)$ & $34(46.6)$ & 0.004 \\
\hline $\begin{array}{l}\text { Optimal cytoreduction } \\
(\mathrm{n}, \%)\end{array}$ & $67(68.4)$ & $54(73.9)$ & NS \\
\hline Alive (n, \%) & $51(52.0)$ & $42(57.5)$ & NS \\
\hline
\end{tabular}


18 are alive with no evidence of disease, 18 patients are alive with disease, 14 have died of disease and 1 has died (undefined cause). In the positive SSL group (microscopic or macroscopic positive) 3 patients are alive with no evidence of disease, 12 are alive with disease, and 32 have died of disease.

The Kaplan-Meier 2-, 3-, and 5-year OS for the SSL group were $85.5 \%, 65.4 \%$, and $48.6 \%$, respectively, compared to the observation group with $69.1 \%, 46.8 \%$, and $29.0 \%$ (Figure 1, p>0.05). No significant difference was observed in DFS for the SSL and observation groups. While DFS and OS of the negative SSL group were better than the observation group, microscopic and macroscopic positive SSL groups $(\mathrm{p}<.01)$, no significant difference was found between positive SSL and observation groups ( $p$.05). However, DFS and OS (Figure 2) of the microscopic positive SSL group were significantly longer than the macroscopic positive SSL group $(\mathrm{p}<.01)$.

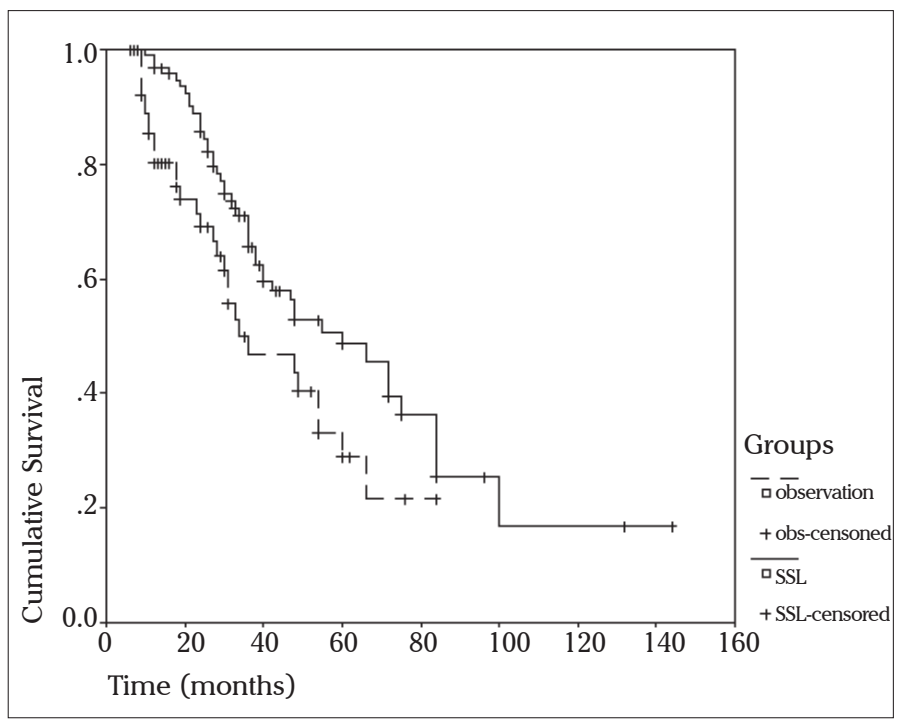

Figure 1. Overall survival for surgical second-look and observation groups (p:not significant)

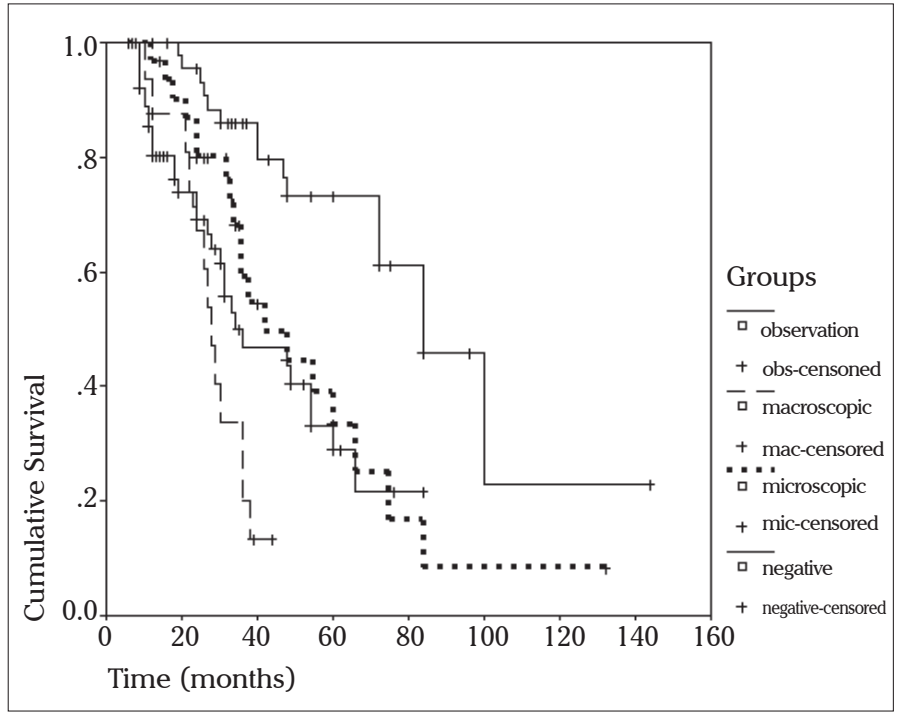

Figure 2. Overall survival of microscopic positive SSL group were significantly longer than macroscopic positive SSL group
Table 2 demonstrates clinical characteristics of the negative and positive SSL groups. While histologic grade, age and ascites volume at the primary surgery were significantly higher in the positive SSL group $(\mathrm{p}<.05)$, optimal cytoreduction rate was higher in the negative SSL group. No significant difference was found for other variables.

Clinical features of patients with negative SSL, with and without recurrence, are summarized in Table 3. Thirty-two patients recurred (62.8\%) after negative SSL and 3.1\%, 40\%, and $68.7 \%$ of recurrences occurred in 1-, 2-, and 3-years after SSL, respectively (Follow-up: mean $=34.09$ months, median $=27$ months, range $=12-120$ months). Only the use of paclitaxel at first-line chemotherapy was seen to prevent recurrence after negative SSL $(p<.05)$. Recurrence after negative SSL was not affected by stage, grade, age, CA-125 level, ascites volume, histologic type or optimal cytoreduction.

\section{Discussion}

SSL remains the best means in hand to evaluate the actual disease status in an ovarian cancer patient clinically free of disease after primary surgery and chemotherapy. Nearly half of these patients turn out to be positive after SSL. Negative SSL rates remain nearly constant for years, ranging from $35 \%$ to $55.1 \%(3,4)$. The $52.0 \%$ incidence of negative SSL in this study is also similar. This result demonstrated once more that clinically complete response does not reflect actual disease status after primary therapy,in approximately half of the patients.

Recurrence rates following negative SSL remain unacceptably high, and reported to range between 27.9 and $61 \%$ (2, 4-6). Therefore negative SSL does not mean a cure. Inadequate sampling, or recurrences hard to visualize, e.g. hindered by adhesions, located in the retroperitoneum or lesser sac, are proposed as possible reasons underlying "false negativity". In our series, $62.8 \%$ recurred after negative $\mathrm{SSL}$. All recurrences were identified at least 1 year after SSL, and 2/3 of the cases between 1st and 3rd years. Previously, half of the recurrences following negative SSL were reported to occur in the first 2 years (6). Thus, negative SSL does not seem to be a precise indicator for discontinuation of chemotherapy. Barakat et al. (7) compared recurrence rates following negative SSL in stage II-IV patients in consolidation chemotherapy (intraperitoneal cisplatin and etoposid) and observation arms as 39 and 54\% respectively. Similarly Tournigand et al. (8) reported survival benefit with use of intraperitoneal chemotherapy for consolidation. On the other hand, Gadducci et al. (2) and Varia et al. (6) could not detect any survival benefit between observation and consolidation chemotherapy after negative SSL. Therefore, more efficient new consolidation chemotherapy protocols should be investigated and may be reserved for patients under high recurrence risk after negative SSL $(9,10)$. Patients with negative SSL may constitute suitable randomization groups for these investigations.

Stage, histologic grade, amount of residual disease after first operation (5), age, chemotherapy protocol $(11,12)$ and initial disease in the omentum (6) were among the proposed risk factors for recurrence after negative SSL. Neither these, nor ascites, optimal cytoreduction at primary surgery or CA-125 at 
Table 2. Comparison features of patients with Negative and Positive SSL results

\begin{tabular}{|c|c|c|c|}
\hline & $\begin{array}{l}\text { Negative SSL } \\
\quad(n=51)\end{array}$ & $\begin{array}{l}\text { Positive SSL* } \\
\quad(n=47)\end{array}$ & $\mathbf{p}$ \\
\hline Age, mean (years) & 50.8 & 55.8 & 0.03 \\
\hline \multicolumn{3}{|l|}{ Stage (n, \%) } & \multirow[t]{5}{*}{ NS } \\
\hline I & $2(3.9)$ & $1(2.1)$ & \\
\hline II & $3(5.9)$ & 0 & \\
\hline III & $45(88.2)$ & $45(95.7)$ & \\
\hline IV & $1(2.0)$ & $1(2.1)$ & \\
\hline \multicolumn{3}{|l|}{ Grade (n, \%) } & \multirow[t]{4}{*}{0.03} \\
\hline 1 & $9(17.6)$ & $1(2.1)$ & \\
\hline 2 & $18(35.3)$ & $16(34.0)$ & \\
\hline 3 & $24(47.1)$ & $30(63.8)$ & \\
\hline \multicolumn{3}{|l|}{ Histologic type (n, \%) } & \multirow[t]{7}{*}{ NS } \\
\hline Serous & $42(82.3)$ & $41(87.3)$ & \\
\hline Mucinous & $2(3.9)$ & $2(4.3)$ & \\
\hline Endometrioid & $4(7.8)$ & $2(4.3)$ & \\
\hline Clear cell & $1(2)$ & $1(2.1)$ & \\
\hline Mixed & 0 & $1(2.1)$ & \\
\hline Undifferentiated & $2(3.9)$ & 0 & \\
\hline Ascites (ml) & 1229 & 2239 & 0.02 \\
\hline CA-125 (IU/ml) & 445 & 551 & $\mathrm{NS}$ \\
\hline Paclitaxel use (n, \%) & $19(37.3)$ & $12(25.5)$ & NS \\
\hline $\begin{array}{l}\text { Optimal cytoreduction } \\
(\mathrm{n}, \%)\end{array}$ & $40(78.4)$ & $27(57.4)$ & 0.03 \\
\hline
\end{tabular}

diagnosis, were identified as associated with recurrence after negative SSL in our study. However paclitaxel administration in first-line chemotherapy is more common among patients in whom disease did not recur after negative SSL (57.9\% versus $25.0 \%, p=0.01$ ). This result conflicts with Friedman et al. (4) and Varia et al. (6) who detected no association with paclitaxel use in first-line chemotherapy and recurrence after negative SSL.

There are conflicting results in the literature on whether SSL provides survival benefit or not. While some authors state that SSL does not improve DFS or OS $(11,13-16)$, some others $(17,18)$ advocate the opposite. According to our results, DFS and OS are longer in patients with negative SSL than patients in the observation arm. Among those with positive SSL, disease-free and overall survival of microscopic positive cases was longer than macroscopic-positive cases. Also, no significant difference at DFS and OS was determined when the positive SSL group, either micro- or macroscopic, is compared to the observation group. So we can conclude that neither second-line chemotherapy protocols, nor secondary cytoreduction can improve survival up to the negative SSL group status, and information gained with SSL
Table 3. Recurred and no recurred cases after Negative SSL result

\begin{tabular}{|c|c|c|c|}
\hline & $\begin{array}{c}\text { No recurrence } \\
\text { after negative SSL } \\
(n=19,37.2 \%)\end{array}$ & $\begin{array}{c}\text { Recurrence after } \\
\text { negative SSL } \\
(n=32,62.8 \%)\end{array}$ & $\mathbf{p}$ \\
\hline Age, mean (years) & 50.3 & 51.1 & NS \\
\hline \multicolumn{3}{|l|}{ Stage (n, \%) } & \multirow[t]{5}{*}{ NS } \\
\hline I & $1(5.3)$ & $1(3.1)$ & \\
\hline II & $1(5.3)$ & $2(6.3)$ & \\
\hline III & $17(89.5)$ & $28(87.5)$ & \\
\hline IV & 0 & $1(3.1)$ & \\
\hline \multicolumn{3}{|l|}{ Grade (n, \%) } & \multirow[t]{4}{*}{ NS } \\
\hline 1 & $4(21.1)$ & $5(15.6)$ & \\
\hline 2 & $6(31.6)$ & $12(37.5)$ & \\
\hline 3 & $9(47.4)$ & $15(46.9)$ & \\
\hline \multicolumn{3}{|l|}{ Histologic type (n, \%) } & \multirow[t]{6}{*}{ NS } \\
\hline Serous & $16(84.2)$ & $26(81.2)$ & \\
\hline Mucinous & 0 & $2(6.3)$ & \\
\hline Endometrioid & $2(10.5)$ & $2(6.3)$ & \\
\hline Clear cell & $1(5.3)$ & 0 & \\
\hline \multicolumn{3}{|l|}{ Undifferentiated } & \\
\hline Ascites (ml) & 921 & 1412 & NS \\
\hline CA-125 (IU/ml) & 403 & 470 & NS \\
\hline Paclitaxel use (n, \%) & $11(57.9)$ & $8(25.0)$ & 0.01 \\
\hline $\begin{array}{l}\text { Optimal } \\
\text { cytoreduction (n, \%) }\end{array}$ & $16(84.2)$ & $24(75.0)$ & NS \\
\hline
\end{tabular}

Note: Percentage of total given in parentheses. SSL: Surgical second-look. NS: Not significant

does not lead to a survival benefit (when compared to observation). DFS and OS of the negative SSL group is better when compared to the observation group, however SSL did not result in a change in management of this group of patients.

Histological grade, age, and ascites at primary surgery were higher and optimal cytoreduction rate was lower in the positive SSL group, when compared to the negative SSL. Therefore these parameters might have a prognostic significance to predict SSL results, and every effort should be made at initial surgery to resect the tumor as completely as possible. In contrast to its possible association with recurrence after negative SSL, paclitaxel use at first-line chemotherapy was also similar in both negative and positive SSL groups. In addition, stage, histological type, and CA 125 level were also similar. Friedman et al. (4) also reported that paclitaxel use was not associated with negative or positive SSL, in contrast to age and ascites volume which were determined to be risk factors for positive SSL.

Currently there is no better method or marker than SSL to evaluate the response to primary treatment in epithelial ovarian cancer. Nevertheless, the rate of recurrence after negative 
SSL remains high, and secondary efforts following positive SSL could not lead to an obvious survival benefit. Therefore, according to results of this and many other studies, routine use of SSL in the management of epithelial ovarian cancers seems ineffective and unnecessary.

\section{Conflict of interest}

None declared.

\section{References}

1. Greer BE, Bundy BN, Ozols RF, Fowler JM, Clarke-Pearson D, Burger RA et al. Implication of second-look laparotomy in the context of optimally resected stage III ovarian cancer: a non-randomized comparison using an explanatory analysis: a Gynecologic Oncology Group study. Gynecol Oncol 2005; 99: 71-9. [CrossRef]

2. Gadducci A, Sartori E, Maggino T, Zola P, Landoni F, Fanucchi A et al. Analysis of failures after negative second-look in patients with advanced ovarian cancer: an Italian multicenter study. Gynecol Oncol 1998; 68: 150-5. [CrossRef]

3. Gershenson DM, Copeland LJ, Wharton JT, Atkinson EN, Sneige N, Edwards CL et al. Prognosis of surgically determined complete responders in advanced ovarian cancer. Cancer 1985; 55: 1129-35. [CrossRef]

4. Friedman RL, Eisenkop SM, Wang HJ. Second-look laparotomy for ovarian cancer provides reliable prognostic information and improves survival. Gynecol Oncol 1997; 67: 88-94. [CrossRef]

5. Rubin SC, Hoskins WJ, Saigo PE, Chapman D, Hakes TB, Markman $\mathrm{M}$ et al. Prognostic factors for recurrence following negative second-look laparotomy in ovarian cancer patients treated with platinum-based chemotherapy. Gynecol Oncol 1991; 42: 137-41. [CrossRef]

6. Varia MA, Stehman FB, Bundy BN, Benda JA, Clarke-Pearson DL, Alvarez RD et al. Intraperitoneal radioactive phosphorus (32P) versus observation after negative second-look laparotomy for satage III ovarian carcinoma: a randomized trial of the Gynecologic Oncology Group. J Clin Oncol 2003; 21: 2849-55. [CrossRef]

7. Barakat RR, Almadrones L, Venkatraman ES, Aghajanian C, Brown $\mathrm{C}$, Shapiro $\mathrm{F}$ et al. A phase II trial of intraperitoneal cisplatin and eto- poside as consolidation therapy in patients with stage II-IV epithelial ovarian cancer following negative surgical assessment. Gynecol Oncol 1998; 69: 17-22. [CrossRef]

8. Tournigand C, Louvet C, Molitor JL, Fritel X, Dehni N, Sezeur A et al. Long-term survival with consolidation intraperitoneal chemotherapy for patients with advanced ovarian cancer with pathological complete remission. Gynecol Oncol. 2003; 91: 341-5. [CrossRef]

9. Ayhan A, Urman B, Yarali H, Yüce K, Ayhan A. Predictors of recurrent disease after negative second-look laparotomy for epithelial ovarian cancer. J Surg Oncol 1990; 44: 119-21. [CrossRef]

10. Podratz KC, Malkasian GD Jr, Wieand HS, Cha SS, Lee RA, Stanhope $\mathrm{CR}$ et al. Recurrent disease after negative second-look laparotomy in stage III and IV ovarian carcinoma. Gynecol Oncol 1988; 29: 274-82. [CrossRef]

11. Potter ME, Hatch KD, Soong SJ, Partridge EE, Austin JM, Shingleton HM. Second-look laparotomy and salvage treatment: a research modality only? Gynecol Oncol 1992; 44: 3-9. [CrossRef]

12. Berek JS, Hacker NF, Lagasse LD, Poth T, Resnick B, Niebert BK. Second-look laparotomy in stage III epithelial ovarian cancer; clinical variables associated with disease status. Obstet Gynecol 1984; 64: 207-12.

13. Luesley D, Lawton F, Blackledge G, Hilton C, Kelly K, Rollason T et al. Failure of second-look laparotomy to influence survival in epithelial ovarian cancer. Lancet 1988; 2: 599-603.

14. Nicoletto MO, Tumolo S, Talamini R, Salvagno L, Franceschi S, Visonà E et al. Surgical second look in ovarian cancer: a randomized study in patients with laparoscopic complete remission-A Northeastern Oncology Cooperative Group- Ovarian Cancer Cooperative Group study. J Clin Oncol 1997; 15: 994 -999.

15. Kamura T, Tsukamoto N, Saito T, Kaku T, Matsuyama T, Nakano H. Efficacy of secondlook laparotomy for patients with epithelial ovarian carcinoma. Int J Gynecol Obstet 1990; 33: 141-7. [CrossRef]

16. Miller DS, Spirtos NM, Ballon SC, Cox RS, Soriero OM, Teng NN. Critical reassessment of second-look laparotomy for epithelial ovarian carcinoma. Cancer 1992; 69: 502-10. [CrossRef]

17. Gallup DG, Talledo OE, Dudzinski MR, Brown KW. Another look at the second-look assessment procedure for ovarian epithelial carcinoma. Am J Obstet Gynecol 1987; 157: 590-6.

18. Tuxen MK, Strauss G, Lund B, Hansen M. The role of secondlook laparotomy in the long-term survival in ovarian cancer. Ann Oncol 1997; 8: 643-8. [CrossRef] 